\title{
Structural and Functional Variations of the Macrobenthic Community of the Adige Basin along the River Continuum
}

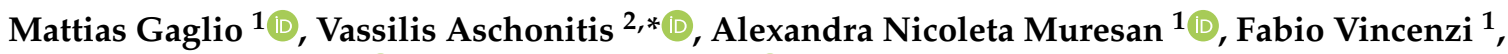 \\ Giuseppe Castaldelli ${ }^{1}$ (D) and Elisa Anna Fano ${ }^{1}$ (D) \\ 1 Department of Life Sciences and Biotechnology, University of Ferrara, 44121 Ferrara, Italy; \\ gglmts@unife.it (M.G.); mrslnd@unife.it (A.N.M.); fabio.vincenzi@unife.it (F.V.); ctg@unife.it (G.C.); \\ fne@unife.it (E.A.F.) \\ 2 Soil and Water Resources Institute, Hellenic Agricultural Organization—Demeter, 57001 Thessaloniki, Greece \\ * Correspondence: v.aschonitis@swri.gr
}

check for updates

Citation: Gaglio, M.; Aschonitis, V.; Muresan, A.N.; Vincenzi, F.; Castaldelli, G.; Fano, E.A. Structural and Functional Variations of the Macrobenthic Community of the Adige Basin along the River Continuum. Water 2021, 13, 451. https://doi.org/10.3390/w13040451

Academic Editor: Christophe Piscart Received: 27 December 2020

Accepted: 5 February 2021

Published: 9 February 2021

Publisher's Note: MDPI stays neutral with regard to jurisdictional claims in published maps and institutional affiliations.

Copyright: (C) 2021 by the authors. Licensee MDPI, Basel, Switzerland. This article is an open access article distributed under the terms and conditions of the Creative Commons Attribution (CC BY) license (https:// creativecommons.org/licenses/by/ $4.0 /)$.

\begin{abstract}
Since the publication of the River Continuum Concept (RCC), the capacity of the longitudinal dimension to predict the distribution of species and ecological functions in river networks was discussed by different river theories. The taxonomic structures and functional attributes of macrobenthic communities were investigated along the river continuum in the river Adige network (Northern Italy), with the aim to test the reliability of RCC theory and clarify the relation between structural and functional features in lotic systems. Distance from the spring was found to be most representative proxy among environmental parameters. The analysis highlighted the decrease of biodiversity levels along the river continuum. The decrease of taxonomic diversity corresponded to the loss in functional richness. The abundances of predator and walker taxa, as well as semelparous organisms, declined along the longitudinal gradient, suggesting variations in community complexity and granulometry. Regression models also depicted the presence of disturbed communities in the central section of the basin, where intensive agricultural activities occur, that affected environmental gradients. Overall, results offered evidences that the river continuum may predict macrobenthic community structures in terms of taxonomic diversity, thus confirming the general validity of RCC. Nonetheless, the functional analysis did not provide equally clear evidences to support the theory. After four decades from its postulation, the RCC is still a reliable model to predict the general macroinvertebrates distribution. However, community functions may respond to a number of local factors not considered in RCC, which could find a declination in other theories. The relations between structural and functional features confirmed to be complex and sensitive to disturbances and local conditions.
\end{abstract}

Keywords: river continuum concept; longitudinal gradient; functional traits; functional indexes; diversity indexes; river theories; macroinvertebrates

\section{Introduction}

Sustainable development strictly depends on the good ecological status of aquatic ecosystems, which encompasses both structural and functional features. This concept is also stated by the EU Water Framework Directive (WFD) [1], which defined the ecological status as "an expression of the quality of the structure and functioning of aquatic ecosystems associated with surface waters". The understanding of both taxa distribution patterns and ecological functioning of lotic ecosystems is therefore fundamental for the management of aquatic environments and the reaching of sustainable goals.

Nonetheless, the relations between community structures and functions in river networks are not fully understood. Since the publication of the River Continuum Concept (RCC) [2], river ecologists investigated the spatial patterns of taxa distribution and ecological processes in lotic systems. The RCC theory represents a milestone in aquatic science, 
providing the first unified synthesis of structures and processes distribution along springmouth gradient. The theory postulates that aquatic communities are structured differently to optimize energy use, according to the variation of physical attributes and the availability of food resources that occur longitudinally along the river continuum. After its publication, several efforts were made to discuss its general validity and to provide new river theories. Doretto et al. [3] recently revised the role of RCC in shaping river ecology along its 40-years history and illustrated how other river theories and approaches were developed to overcome its main limitations. In general, the latter can be synthetized in the missing consideration for local heterogeneity. For instance, the metacommunity approach was proposed to include species dispersal effects, thus considering both species sorting and mass effects to predict taxa distributions [4]. Since the RCC is focused on the main stem stream and omits to frame the river in the context of river network, including its interruptions and disturbances, many studies tried to model the river system within new framework. While some theories, such as the Flood Pulse Concept (FPC) [5] and the Serial Discontinuity Concept (SDC) [6], were developed to describe more specific contexts, other recent models provide more comprehensive attempts to unify the overview of the river network. The Riverine Ecosystem Synthesis (RES) [7] frames the river as longitudinal arrangements of functionally and structurally similar functional process zones, defined by shifts in hydrological and geomorphological conditions. Rivers are thus viewed as downstream mosaics of large hydrogeomorphic patches, whose features determine the delivery of ecological processes and the occurrence of taxa. The Network Position Hypothesis (NPH) $[8,9]$ further implemented the metacommunity theory in the river network with respect to the position within the river network. The authors state that headwater communities are mainly influenced by species sorting, while downstream assemblages are driven by dispersal-related dynamics. Beside the debate on the validity of the RCC, the role of the river continuum on shaping biotic communities is still steadily considered in river ecology [10-12]. Most of the other abovementioned river theories are reconcilable with the theory of RCC, introducing exceptions and adjustments to general framework of river continuum and extending the concept of river continuum beyond the original model of Vannote et al. [2].

Since macrobenthic communities are fundamental for ecosystem functioning, they represent ideal models for the study of river systems. In fact, macrobenthic invertebrates process a significant amount of organic matter, and they constitute food resources for crustacean, fishes, and birds, thus transferring relevant energy amounts from primary producers to higher trophic levels $[13,14]$. They are also suitable indicators for local environmental conditions, due to their reduced capacity to move actively in aquatic ecosystems. Therefore, macroinvertebrate assemblages can be used to investigate variations in ecosystem functioning and environmental conditions $[15,16]$.

Alpine rivers are good examples of impacted lotic systems, where actions for environmental conservation are urgently needed [17]. Alpine rivers and streams suffer from a variety of stressors related to human activities and climate change, which lead to major losses of freshwater biodiversity and ecosystem services [18,19]. An ideal model for such investigations is Adige river [20], which is among the longest of the alpine area. In fact, due to its importance and the presence of both natural and anthropic features in its catchments, it has been one of the most important areas for studying macroinvertebrate assemblages since a long time ago [21]. The first ecological studies [22,23] found that macrobenthic fauna accumulated pollutants from surrounding industries and other human activities. More recently, Giulivo et al. [24] analyzed the structural response of the macrobenthic community of Adige river to seasonality and environmental stressors. They found that human stressors, such as streamflow alteration and pollutants, affect the community composition but not the diversity. Functional attributes were investigated by De Castro-Català et al. [25] in the Adige and others two European rivers, where common trends were observed. Particularly, functional and structural indices were significantly correlated, and taxa richness was found to be the best predictor for pesticide concentrations. Larsen et al. [11] studied the functional 
feeding habits of macrobenthic assemblages using a geostatistical method and observed that, even following a heterogeneous pattern along the longitudinal gradient, the distribution of feeding functional groups was generally consistent with the RCC. Similar outcomes were observed by Pollice et al. [18] for structural composition of macrobenthic community of Adige and other alpine streams and rivers using asymmetric eigenvector maps that are used to detect the influence of directional spatial processes on the taxa distribution.

The aim of the study is to test the reliability of RCC theory by investigating structural and functional attributes of macrobenthic communities of the river Adige basin along the river continuum. The study will also allow to clarify the relation between structural and functional features in lotic systems. Unlike the other abovementioned works carried out in Adige river and other nearby systems, the present study considers taxonomic structures and a more comprehensive range of functional and biological traits. The results will contribute by shedding light on the relation between structural and functional features of the macrobenthic community along an important alpine lotic system, as well as by reevaluating the capacity of RCC theory for the specific river.

\section{Materials and Methods}

\subsection{Study Area}

The Adige river flows for $410 \mathrm{~km}$, and it is the second longest river, hosted in the third largest watershed $\left(12,200 \mathrm{~km}^{2}\right)$ in Italy. The spring is near the Lake Resia at $1586 \mathrm{~m}$ a.s.l., and the river reaches the Adriatic Sea at the south of Venice lagoon. The hydrological regime follows the typical pattern of alpine rivers, with higher discharges in summer due to snow melt. The higher values of mean monthly discharge at lower gauge station (located in Boara Pisani) occur in June with a decreasing trend $\left(373 \mathrm{~m}^{3} / \mathrm{s}\right.$ for the period $1928-1990$ and $292 \mathrm{~m}^{3} / \mathrm{s}$ for the period 2004-2016). The Adige basin (Figure 1) includes 8 tributaries, mainly flowing in the upper section, characterized by a forest-dominated landscape. The upper section of the river is surrounded by typical alpine landscape features, and it is mainly impacted by hydropower dams, while its mid and lower sections are stressed by the nutrients' leaching by the intensive agricultural activities and livestock farming. The dramatic rise of fertilizer rates in the basin in the last decades severely harmed ecosystem services and water quality [19], representing a stressor of increasing relevance.

\subsection{Sampling Methodology, Community Indices and Environmental Descriptors}

Macrobenthic assemblages are ideal models for the investigation of the effects of environmental features on living communities and were therefore chosen to test the prediction of the RCC in river networks, as well as to study relations between community structures and functions. Macrobenthic samples were collected during summer season (2009-2013) from 15 sites along the main course of Adige river and 9 sites from tributaries (24 sampling sites in total) (Figure 1). Benthic macrofauna was collected by sweeping a $40 \mathrm{~cm}$ wide D-frame hand net (mesh size $=500 \mu \mathrm{m}$ ) in an area of $1 \mathrm{~m}^{2}$, after suspending the sediment $1 \mathrm{~m}$ upstream by kicking. Five replicates per site were sampled. After being fixed in $4 \%$ formalin solution, the animals were brought to laboratory to be classified. A total of 63 taxa were recorded (Table 1). Both structural and functional indices were computed to study macrobenthic community attributes and test RCC predictions with respect to environmental conditions. Individual abundances were expressed as individuals per area unit (ind. $\mathrm{m}^{-2}$ ). The considered taxonomic indices for structural composition were the following: taxa richness $(\mathrm{S})$, individuals' abundance $(\mathrm{N})$, Shannon-Wiener index $\left(\mathrm{H}^{\prime}\right)$, Pielou index (J), Margaref index (d) and Simpson index (lambda). Functional analysis was based on six biological and functional traits attributed to each taxon: functional feeding group, mobility, adult life habitat, life span, reproductive frequency and habitat choice. Such attributes were used to calculate three functional indices using the "FD" package for $\mathrm{R}$ [26], which takes into account multidimensional (i.e., multiple traits) functional diversity: Functional richness (Fric), Functional evenness (Feve) and Rao quadratic entropy index 
(RaoQ). The assignment of biological and functional attributes was carried out at genera level based on database available in the literature [27,28].

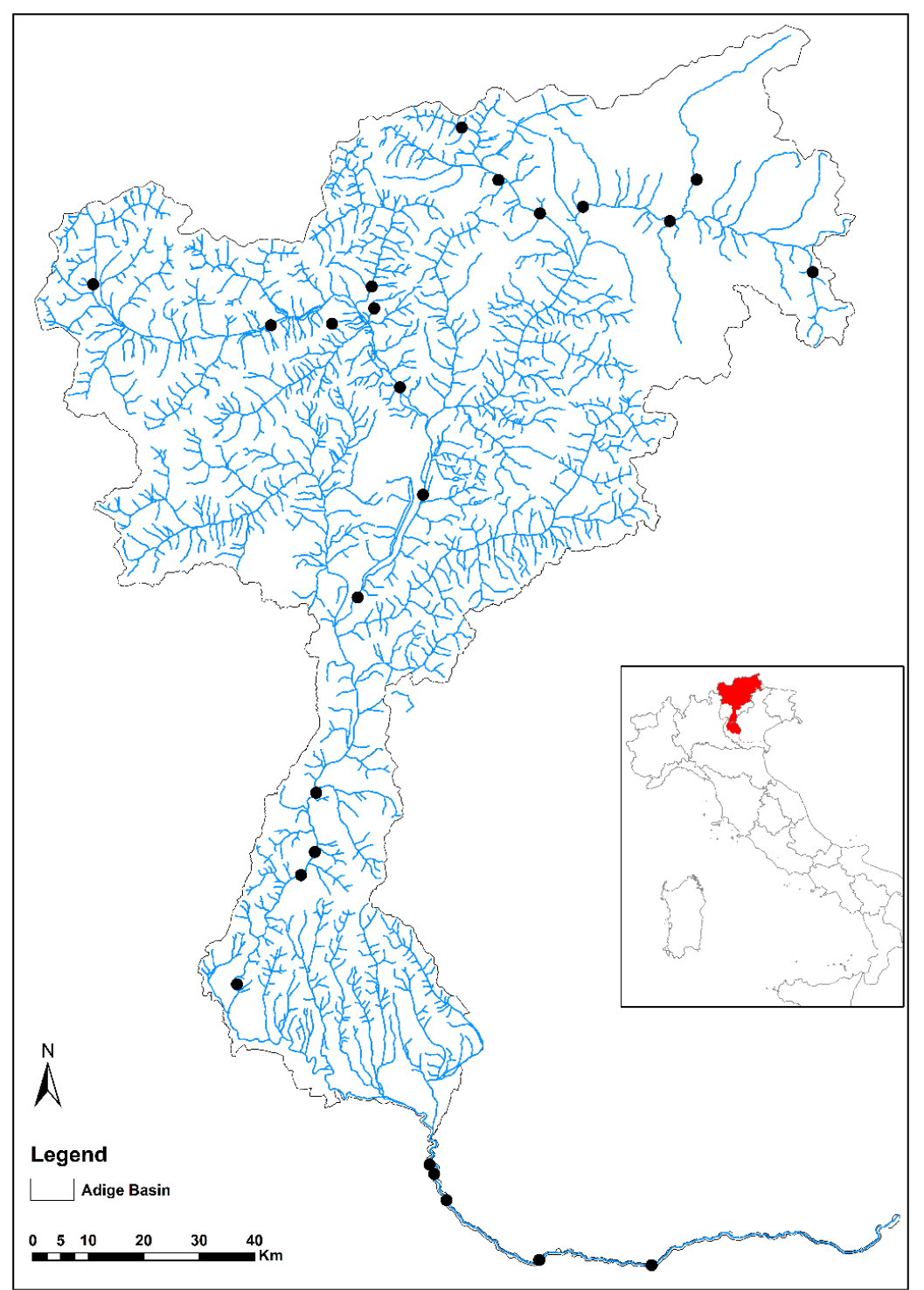

Figure 1. Sampling stations within the river network of the Adige basin.

Table 1. List of the taxa recorded in the analysis. The classification was performed at Genus level when possible. Alternatively, coarser taxonomic levels are specified.

\begin{tabular}{|c|c|c|c|c|c|c|c|}
\hline \multirow{2}{*}{$\begin{array}{c}\text { Groups } \\
\text { Hyrudinea }\end{array}$} & \multicolumn{2}{|c|}{ Taxonomic Level } & \multirow{2}{*}{$\frac{\text { Abbreviation }}{E r p}$} & \multirow{3}{*}{$\begin{array}{c}\text { Groups } \\
\text { Heteroptera } \\
\text { Odonata }\end{array}$} & \multicolumn{2}{|c|}{ Taxonomic Level } & \multirow{2}{*}{$\frac{\text { Abbreviation }}{\text { Cori }}$} \\
\hline & & Dina & & & $\mathrm{F}$ & Corixidae & \\
\hline & & Glossiphonia & Glo & & & Coneagrion & Coe \\
\hline \multirow[t]{2}{*}{ Oligochaeta } & $\mathrm{F}$ & Lumbricidae & Lum & Plecoptera & & Capnia & Cap \\
\hline & $\mathrm{F}$ & Naididae & Nai & & & Chloroperla & Chl \\
\hline Trombidiformes & $\mathrm{F}$ & Hydracarina & Hyd & & & Leuctra & Leu \\
\hline Amphipoda & & Gammarus & Gam & & & Nemoura & Nem \\
\hline Isopoda & & Asellus & Ase & & & Dinocras & Per \\
\hline \multirow[t]{5}{*}{ Coleoptera } & & Dytiscus & Dyt & & & Isoperla & Perl \\
\hline & & Esolus & Elm & & & Taeniopterix & Tae \\
\hline & & Limnius & Elmi & Trichoptera & & Brachycentrus & Bra \\
\hline & & Hydraena & Hydra & & $\mathrm{F}$ & Glossosomatidae & Glo \\
\hline & & Berosus & Hydro & & & Hydropsyche & Hydrops \\
\hline
\end{tabular}


Table 1. Cont

\begin{tabular}{|c|c|c|c|c|c|c|c|}
\hline Groups & \multicolumn{2}{|c|}{ Taxonomic Level } & Abbreviation & Groups & \multicolumn{2}{|c|}{ Taxonomic Level } & Abbreviation \\
\hline \multirow[t]{16}{*}{ Diptera } & & Anthomyia & Ant & & \multirow{10}{*}{$\mathrm{F}$} & Hydroptila & Hytrop \\
\hline & & Atherix & Ath & & & Lepidostoma & Lep \\
\hline & & Blepharicera & Ble & & & Allogamus & Limn \\
\hline & & Bezzia & Cer & & & Philopotamus & Phi \\
\hline & $\mathrm{SF}$ & Chironominae & Chi & & & Polycentropus & Pol \\
\hline & $\mathrm{T}$ & Corynoneurini & Cor & & & Psychomiidae & Psyc \\
\hline & $\mathrm{F}$ & Dolichopodidae & Dol & & & Rhyacophila & Rhy \\
\hline & \multirow[t]{2}{*}{$\mathrm{F}$} & Empididae & Emp & & & Sericostoma & Ser \\
\hline & & Hexatoma & Lim & Bivalvia & & Sphaerium & Sph \\
\hline & $\mathrm{SF}$ & Orthocladiinae & Ort & Gasteropoda & & Aplexa & Phy \\
\hline & \multirow[t]{3}{*}{ SF } & Prodiamesinae & Pro & & & Bithynella & Bit \\
\hline & & Pericoma & Psy & & & Lymnea & Lym \\
\hline & & Simulium & Sim & & & Theodoxus & Ner \\
\hline & \multirow[t]{3}{*}{ SF } & Tanypodinae & Tan & & & Planorbis & Pla \\
\hline & & Tanytarsus & Tany & & & Valvata & Val \\
\hline & & Tipula & Tip & Nematoda & $\mathrm{P}$ & & Nem \\
\hline \multirow[t]{4}{*}{ Ephemeroptera } & & Baetis & Bae & Turbellaria & & Dugesia & Dug \\
\hline & & Caenis & Cae & & & Planaria & Plan \\
\hline & & Ephemerella & Eph & & & Polycelis & Den \\
\hline & & Ecdyonurus & Hep & & & & \\
\hline
\end{tabular}

P, Phylum; F, family; SF, subfamily; T, tribe.

Nine environmental factors were measured to characterize the river continuum and local variability (Table 2). The distance of the sampling stations, as a main descriptor for the river continuum, from the river spring was measured using Google Earth images. Altitude was recorded using a GPS device (Garmin 72 H, Garmin Ltd., Schaffhausen, Switzerland). Water temperature and dissolved oxygen concentration were measured using a multiparameter probe (YSI Model 85, YSI Incorporated, Yellow Springs, OH, USA), mean water depth and streambed width were measured with a metric cord. Granulometry was measured using an analytical sieve shaker (Fritsch Analysensieb DIN 4188, FRITSCH $\mathrm{GmbH}-$ Milling and Sizing, Idar-Oberstein, Germany) and expressed with Krumbein $(\varphi)$ scale [29]. The latter expresses the sediment size range according a logarithmic modification of the Wentworth scale. Finally, $\mathrm{NO}_{3}{ }^{-}$and $\mathrm{NH}_{4}{ }^{+}$were measured following the automatic colorimeter method using Technicon AutoAnalyser II (SEAL Analytical Ltd., Southampton, United Kingdom) [30,31] and the Bower and Holm-Hansen protocol [32], respectively.

Table 2. Environmental parameters and related units measured in the river Adige network. Maximum, minimum, mean and standard deviation values are reported. Please, note that granulometry size is expressed using a logarithmic scale $(\varphi)$.

\begin{tabular}{ccccccc}
\hline Parameter & Unit & Abbreviation & Max & Min & Mean & St.Dev. \\
\hline Altitude & $\mathrm{m} \mathrm{a.s.l.}$ & $\mathrm{Alt}$ & 1270 & 8 & 449.58 & 411.27 \\
Granulometry & $\varphi$ & $\mathrm{Gran}$ & 5 & -7 & 0.46 & 3.86 \\
Nitrate concentration & $\mathrm{mg} \mathrm{L}^{-1}$ & $\mathrm{NO}_{3}^{-}$ & 1.58 & 0.08 & 0.47 & 0.31 \\
Ammonia concentration & $\mathrm{mg} \mathrm{L}^{-1}$ & $\mathrm{NH}_{4}^{+}$ & 361.73 & 11 & 61.16 & 77.54 \\
Distance from spring & $\mathrm{km}$ & $\mathrm{Dist}$ & 356 & 10 & 132.38 & 116.29 \\
Streambed width & $\mathrm{m}$ & Width & 125 & 2 & 58.33 & 49.86 \\
Water Depth & $\mathrm{cm}$ & Depth & 105 & 15 & 57.71 & 36.56 \\
Temperature & ${ }^{\circ} \mathrm{C}$ & $\mathrm{Temp}$ & 18.8 & 7.8 & 3.32 & 3.61 \\
Oxygen concentration & $\mathrm{mg} \mathrm{L}^{-1}$ & $\mathrm{O}_{2}$ & 11.02 & 7.5 & 9.52 & 0.77 \\
\hline
\end{tabular}

\subsection{Methods of Analysis}

Since the RCC assumes the co-presence of different environmental gradients along a longitudinal dimension, the distance between the spring and sample sites was selected as ideal descriptor to study the prediction capacity of the RCC. Spearman's rank correlation coefficient was used to investigate the correlations among environmental variables and to 
evaluate if the distance from the source (Dist) adequately includes the effects of the rest environmental variables. Then, its relation to biological traits and community indices was investigated by selecting the most appropriate regression models using Excel for selecting the form and $\mathrm{R}$ language for assessing the statistical significance of regression models using the "nls.lm" function of the \{minpack. $1 \mathrm{~m}\}$ tool. The reason of including regression models was based on the presence of unimodal responses.

\section{Results}

The Spearman correlations among environmental variables of Table 2 are given in Table 3, where the very low and non-significant correlation of $\mathrm{NO}_{3}{ }^{-}$and $\mathrm{NH}_{4}{ }^{+}$with all the rest environmental parameters is observed. On the other hand, all the rest parameters Alt, Gran, Dist, Width, Depth, Temp and $\mathrm{O}_{2}$ present statistically significant correlations. Among them, Dist parameter presents the higher mean absolute value of Spearman correlations with all the rest parameters without considering $\mathrm{NO}_{3}{ }^{-}$and $\mathrm{NH}_{4}{ }^{+}$(Figure 2). These results show that Dist can adequately describes the effects of topography, hydromorphology and physical water parameters but not those associated to chemical water parameters that are closely associated to human activities like agriculture.

Table 3. Spearman (r) correlations among environmental variables (low half) and their $p$-values in italics (upper half).

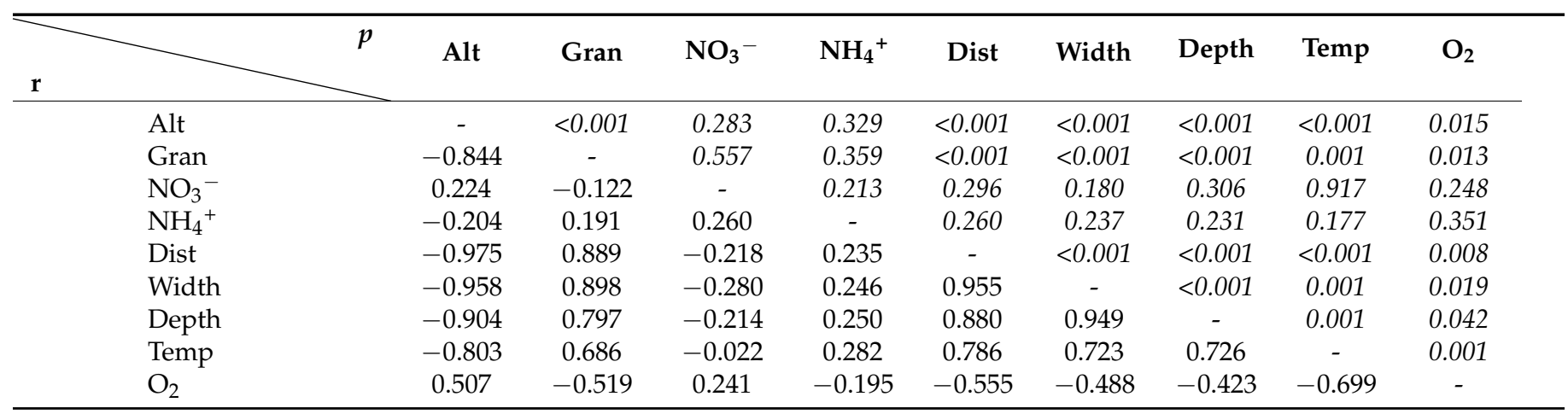

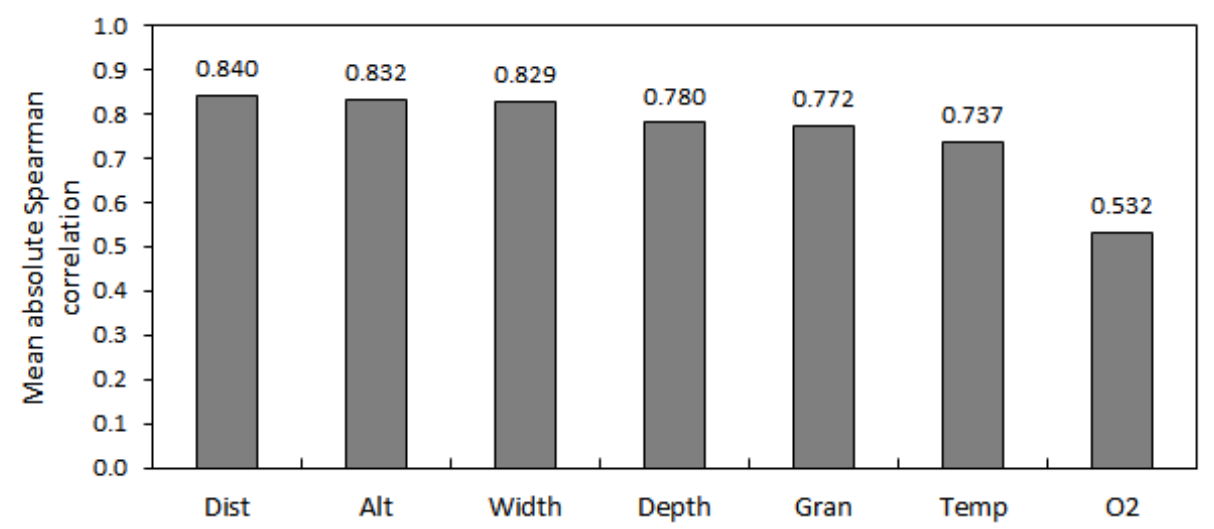

Figure 2. Mean absolute spearman correlation of each parameter with all the rest $\left(\mathrm{NO}_{3}{ }^{-}\right.$and $\mathrm{NH}_{4}{ }^{+}$ correlations with parameters on the graph are excluded).

Therefore, the distance from the spring (Dist) was confirmed to be an optimum descriptor for data variability and can be robustly contrasted with community indices and biological/functional traits. The most fitted regression models for community indices are presented in Table 4 and Figure 3. Statistically significant regression models were found for all the taxonomic indices except $\mathrm{N}$ and for only one functional index (FRic). Negative exponential monotonous models were chosen for $\mathrm{S}, \mathrm{d}$ and Fric, while polynomial relations were selected for $\mathrm{H}^{\prime}, \mathrm{J}$ and $\lambda$ with the latter two showing a clear decreasing trend at central values. Table 5 shows the statistically significant regression models selected for 
the biological traits. Among the feeding groups, "predators" is the only attribute with a significant relation. Other statistically significant results were observed for adult life (both aquatic and aeric life habits), mobility (walker taxa) and reproductive frequency (semelparous taxa). No significant variations along Dist gradient were found for life span and habitat choice. Aquatic adult life habit is the only significant attribute showing polynomial/unimodal relation with Dist with higher individual densities at central Dist values, while a negative exponentially relation was found for the other traits (Figure 4).

Table 4. Most fitted regression models between Distance from the source and the community index (S-Species richness; $\mathrm{N}$-Individuals abundance; $\mathrm{H}^{\prime}$ —Shannon-Wienner Index; d-Margalef Index; J—Pielou Index; $\lambda$-Simpson Index; FRicFunctional Richness; FEve-Functional Evenness; RaoQ—Rao Quadratic Entropy) (Exp-exponential; Pol—Polynomial).

\begin{tabular}{ccccc}
\hline Index & $p$-Value & $\mathbf{R}^{2}$ & Model & Equation \\
\hline S & $* *$ & 0.6751 & Exp & $\mathrm{y}=31.597 \exp (-0.003 \mathrm{x})$ \\
$\mathrm{N}$ & $\mathrm{ns}$ & - & - & - \\
$\mathrm{H}^{\prime}$ & $* * *$ & 0.7296 & Pol & $\mathrm{y}=2 \times 10^{-5} \mathrm{x}^{2}-0.0102 \mathrm{x}+2.8927$ \\
$\mathrm{~d}$ & $* * *$ & 0.6012 & Exp & $\mathrm{y}=4.6303 \exp (-0.003 \mathrm{x})$ \\
$\mathrm{J}$ & $* * *$ & 0.5523 & Pol & $\mathrm{y}=8 \times 10^{-6} \mathrm{x}^{2}-0.0034 \mathrm{x}+0.8908$ \\
$\lambda$ & $* *$ & 0.5617 & Pol & $\mathrm{y}=5 \times 10^{-6} \mathrm{x}^{2}-0.0027 \mathrm{x}+0.9768$ \\
FRic & $\mathrm{ns}$ & - & - & $\mathrm{y}=26.239 \exp (-0.003 \mathrm{x})$ \\
FEve & $\mathrm{ns}$ & - & - & - \\
RaoQ & & & - & - \\
\hline
\end{tabular}

${ }^{* *}<0.01 ; * * * 0.001 ; \mathrm{ns}=$ non-significant.
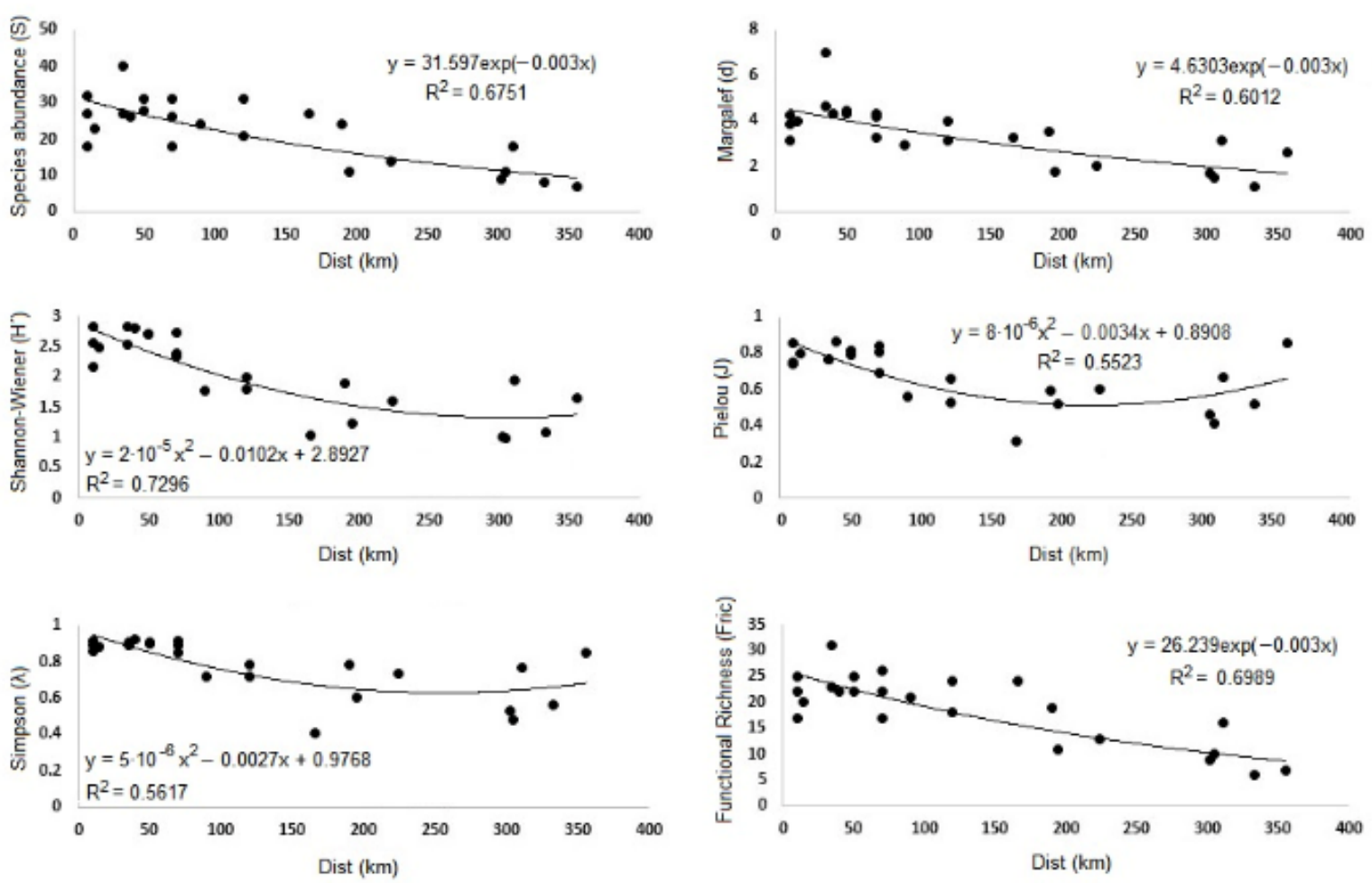

Figure 3. Regression models of distance from the source vs. community indices. 
Table 5. Most fitted regression models between distance from the source and biological traits.

\begin{tabular}{|c|c|c|c|c|c|}
\hline Biolog & Traits & $p$-Value & $\mathbf{R}^{2}$ & Model & Equation \\
\hline \multirow{5}{*}{ Feeding Group } & Deposit Feeder & ns & - & - & - \\
\hline & Predator & $* *$ & 0.6875 & Exp & $y=96.912 \exp (-0.011 x)$ \\
\hline & Scrapers & ns & - & - & - \\
\hline & Shredder & ns & - & - & - \\
\hline & Filter Feeder & ns & - & - & - \\
\hline \multirow{3}{*}{ Mobility } & Burrower & ns & - & - & - \\
\hline & Swimmer & ns & - & - & - \\
\hline & Walker & * & 0.5297 & Exp & $y=211.06 \exp (-0.01 x)$ \\
\hline \multirow{2}{*}{ Adult Life } & Aeric & * & 0.4354 & Exp & $y=657.12 \exp (-0.007 x)$ \\
\hline & Aquatic & * & 0.2395 & Pol & $y=-0.026 x^{2}+9.7326 x-189.26$ \\
\hline \multirow{3}{*}{ Life Span } & Long & ns & - & - & - \\
\hline & Medium & ns & - & - & - \\
\hline & Short & ns & - & - & - \\
\hline \multirow{2}{*}{$\begin{array}{l}\text { Reproductive } \\
\text { Frequency }\end{array}$} & Iteroparous & ns & - & - & - \\
\hline & Semelparous & $*$ & 0.3543 & Exp & $y=474.46 \exp (-0.006 x)$ \\
\hline \multirow{2}{*}{ Habitat Choice } & Generalist & ns & - & - & - \\
\hline & Specialist & ns & - & - & - \\
\hline
\end{tabular}

${ }^{*}<0.05 ;{ }^{* *}<0.001 ; \mathrm{ns}=$ non-significant.
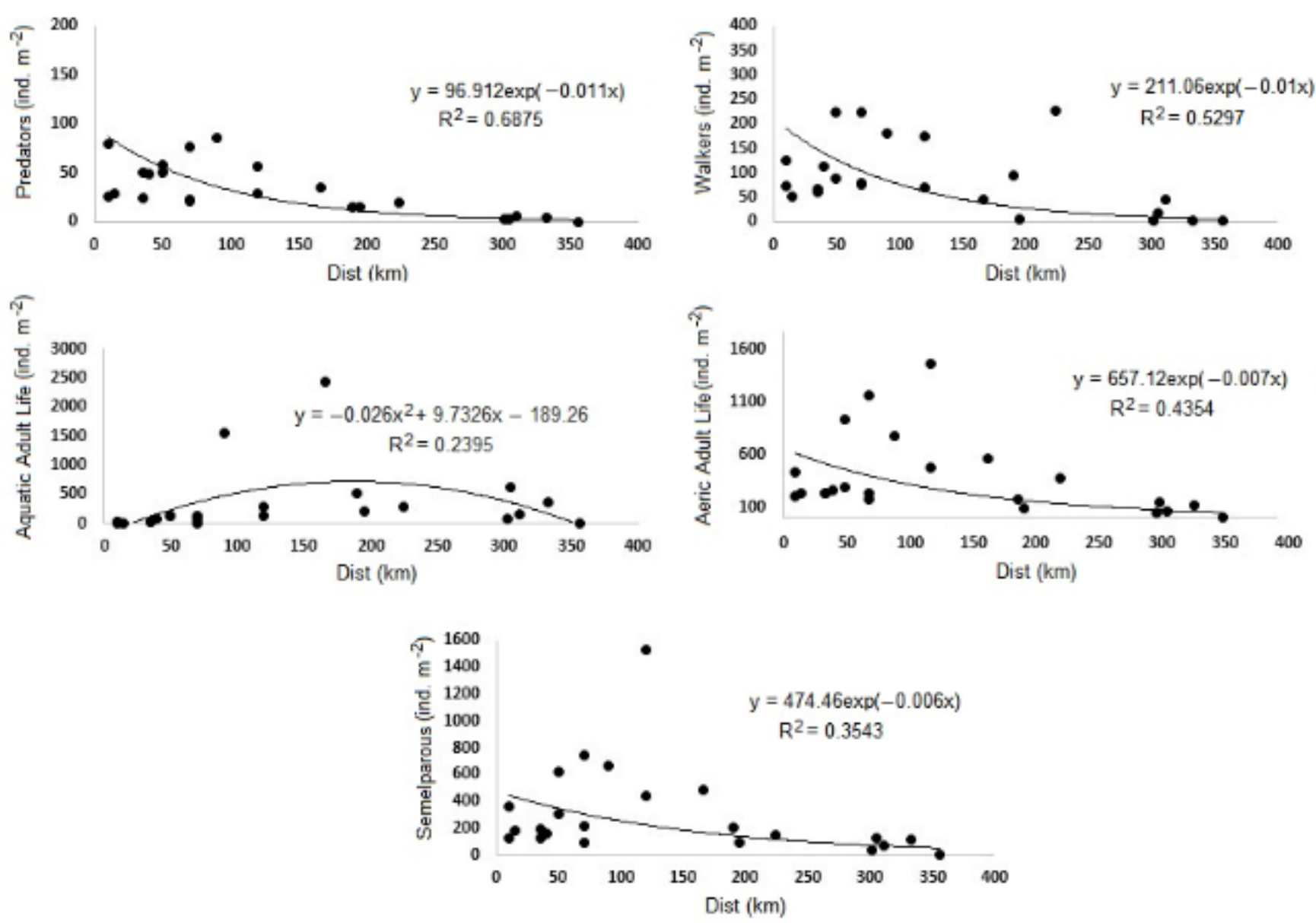

Figure 4. Regression models of distance from the source vs. biological traits. 


\section{Discussion}

The presence of environmental gradients along the river continuum is the central concept at the basis of RCC, and their role on shaping biotic communities still stimulates the scientific debate around river theories. The first result of this study is the observed relevance of the Dist as the most representative proxy of all the most important parameters of topography, hydromorphology and physical water properties except nitrogen species. This confirms the presence of a continuum along the longitudinal gradient and, at least in the case of river Adige, reinforces the basic assumption of RCC. On the other hand, the low correlation of Dist with nitrogen species indicates the limitations of this parameter and consequently of RCC to include the effects of human activities scattered in the basin. This could be the reason why the regression analysis showed unimodal trends with higher or lower peaks for Dist values at approximately $200 \mathrm{~km}$ that alter the river continuum and may be responsible for reducing the capacity of the RCC theory to predict some functional attributes (e.g., shredder abundances). This section of the basin is characterized by the presence of intensive agricultural activities and urban centers that are documented pollution sources threating water quality of Adige river $[19,20]$. The decreasing trend of Pielou evenness (J) and Simpson $(\lambda)$ indices at this longitudinal range showed macrobenthic communities dominated by few taxa, as commonly observed in agricultural impacted aquatic ecosystems, e.g., [33,34]. The analysis of biological traits did not identify any other attribute of these organisms, except from an increase at the medium section of adult aquatic life habit due to increased abundances of oligochaeta. Nevertheless, nutrients alone may not properly capture the wide range of effects of agricultural activities on the river network. In fact, agriculture is also responsible for the runoff of chemical products (e.g., pesticides) in the middle section of river Adige [20].

The results of both structural and functional features of macrobenthic communities can be compared with the findings of other studies carried out in the river Adige or other similar systems. For example, the reliability of Dist to describe taxonomic composition of macrobenthic communities was also demonstrated by Pollice et al. [18] in the river systems of Northern Italy (including river Adige basin). The decrease of predator taxa along the longitudinal gradient of the river Adige network was detected also by Larsen et al. [11], who also found significant patterns for other functional groups that were not confirmed in this study.

It also must be mentioned that flow regimes and disturbance history are additional factors affecting macrobenthic communities. Despite the fact that samplings were carried out during the summer season, when river discharges reach their maximum levels, previous extreme low- and high-flow events occurred in the past could strongly influence macrobenthic communities and ecological processes. At the same time, such extreme events seem to not exert significant influences on geochemical gradients [35] and therefore on the river continuum, thus potentially reducing the dependence of macrobenthic communities on the latter.

The results also demonstrated the complex relations between community structures and functions. Particularly, the analysis suggested that the decrease of species richness, and more generally of taxonomic diversity, corresponds to loss in functional richness (i.e., the number of biological/functional traits observed), as also found by De Castro-Català et al. [25], but not in other functional indices. While it is intuitive that a larger number of taxa delivers a larger range of functions, the loss in species richness does not necessary implies an uneven distribution of functional attributes, a dimension computed in both functional evenness (FEve) and Rao quadratic entropy (RaoQ) indices. In fact, RaoQ values may tend to be negatively correlated with species richness, as described by Botta-Dukat [36]. Moreover, Pakerman's [37] warnings that functional indices are highly sensitive to trait measure errors. The attribution of biological/functional traits using literature data may introduce some errors and omit the capacity of ecological plasticity of some taxa.

As expected, biodiversity levels decreased along the river continuum. Headwater systems present heterogeneous mosaics of habitats and more pristine conditions that support 
the occurrence of higher biodiversity levels, while lower river sections host more disturbed communities $[33,38,39]$. As a consequence, decreasing trends of predators' abundances may depict the loss of structural complexities. The analysis of functional feeding groups in river Adige network does not provide any evidence to support RCC. Local heterogeneity and disturbances may be the cause of the lack of significant patterns for other feeding groups, an explanation that may instead be coherent with other theories. Variation in mobility strategy is an adaptive response to granulometry variations along the continuum in accordance to RCC theory, as demonstrated by the observed decrease of walker taxa along the longitudinal gradient. Nevertheless, some caveats have to be considered with respect to these conclusions. Taxonomic identification relies on investigators' taxonomic skills on the different groups. For this reason, the biodiversity that is analyzed may not exhaustively represent the whole diversity of macrobenthic assemblages nor the biodiversity that would be found by taxonomists of the different groups. Similarly, the attribution of functional and biological traits to each taxonomic group may be affected by the abovementioned limitations.

Overall, in the case of the Adige basin, the results offered evidences that the river continuum may predict macrobenthic community structures in terms of taxonomic diversity, thus confirming the general validity of RCC theory. However, their functional organization may be driven by a number of factors not considered in RCC, such as local patchy habitats, disturbances at different scales and surrounding land cover, which could find a declination in other theories, such as the Riverine Ecosystem Synthesis and the Network Position Hypothesis. Ecological processes as species sorting and source-sink dynamics in non-pristine river networks are likely to be a result of combined effects of other environmental gradients that come along with the longitudinal gradient (e.g., land use and coverage, hydrological alterations and nutrient pollution) $[40,41]$ that were not directly captured by the present analysis. The use of geospatial statistics may harbor the potential to detect such complex relations. However, while demonstrating the validity of theories used on river continuum, the present analysis suggests that future studies should consider both structural and functional indicators, as well as a comprehensive set of biological traits, to capture and describe the complex relations underpinning organisms' distributions in river networks. Finally, the fact that some sampling sites receive water from different springs in the same basin does not reduce the significance of the results but, on the contrary, expands it since it does not consider only the distance from one source but the distance from multiple sources of the same river.

Author Contributions: Conceptualization, M.G., V.A. and E.A.F.; methodology, V.A. and M.G.; software, V.A. and A.N.M.; investigation, A.N.M. and E.A.F.; resources, E.A.F.; data curation, A.N.M., F.V. and E.A.F.; writing-original draft preparation, M.G. and V.A.; writing-review and editing, M.G. and V.A.; visualization, M.G. and A.N.M.; supervision, E.A.F. and G.C. All authors have read and agreed to the published version of the manuscript.

Funding: This research was partially supported by the PRIN-NOACQUA project "Responses of communities and ecosystem processes in intermittent rivers" (Prot. 201572HW8F) funded by the Italian Ministry of Education, University and Research.

Institutional Review Board Statement: Not applicable.

Informed Consent Statement: Not applicable.

Data Availability Statement: The data presented in this study are available on request from the first author. The data are not publicly available due to its current use for preparing a next publication.

Conflicts of Interest: The authors declare no conflict of interest. 


\section{References}

1. Water Framework Directive. Directive 2000/60/EC of the European Parliament and of the Council of 23 October 2000 Establishing a Framework for Community Action in the Field of Water Policy. 2000. Available online: https:/ / eur-lex.europa.eu/legalcontent/EN/TXT/?uri=CELEX\%3A32000L0060 (accessed on 1 November 2020).

2. Vannote, R.L.; Minshall, G.W.; Cummins, K.W.; Sedell, J.R.; Cushing, C.E. The river continuum concept. Can. J. Fish. Aquat. Sci. 1980, 37, 130-137. [CrossRef]

3. Doretto, A.; Piano, E.; Larson, C.E. The River Continuum Concept: Lessons from the past and perspectives for the future. Can. J. Fish. Aquat. Sci. 2020, 77, 1853-1864. [CrossRef]

4. Brown, B.L.; Swan, C.M.; Auerbach, D.A.; Campbell Grant, E.H.; Hitt, N.P.; Maloney, K.O.; Patrick, C. Metacommunity theory as a multispecies, multiscale framework for studying the influence of river network structure on riverine communities and ecosystems. J. N. Am. Benthol. Soc. 2011, 30, 310-327. [CrossRef]

5. Junk, W.J.; Bayley, P.B.; Sparks, R.E. The flood pulse concept in river-floodplain systems.pdf. Can. J. Fish. Aquat. Sci. 1989, 106, 110-127.

6. Ward, J.V.; Stanford, J.A. The serial discontinuity concept: Extending the model to floodplain rivers. Regul. Rivers Res. Manag. 1995, 10, 156-168. [CrossRef]

7. Thorp, J.H.; Thoms, M.C.; Delong, M.D. The riverine ecosystem synthesis: Biocomplexity in river networks across space and time. River Res. Appl. 2006, 22, 123-147. [CrossRef]

8. Benda, L.; Poff, N.L.; Miller, D.; Dunne, T.; Reeves, G.; Pess, G.; Pollock, M. The network dynamics hypothesis: How channel networks structure riverine habitats. Bioscience 2004, 55, 413-427. [CrossRef]

9. Schmera, D.; Árva, D.; Boda, P.; Bódis, E.; Bolgovics, Á.; Borics, G.; Csercsa, A.; Deák, C.; Krasznai, E.; Lukács, B.A.; et al. Does isolation influence the relative role of environmental and dispersal-related processes in stream networks? An empirical test of the network position hypothesis using multiple taxa. Freshw. Biol. 2018, 63, 74-85. [CrossRef]

10. Curtis, W.J.; Gebhard, A.E.; Perkin, J.S. The river continuum concept predicts prey assemblage structure for an insectivorous fish along a temperate riverscape. Freshw. Sci. 2018, 37, 618-630. [CrossRef]

11. Larsen, S.; Bruno, M.C.; Vaughan, I.P.; Zolezzi, G. Testing the River Continuum Concept with geostatistical stream-network models. Ecol. Complex. 2019, 39, 100773. [CrossRef]

12. Jiang, X.; Xiong, J.; Xie, Z.; Chen, Y. Longitudinal patterns of macroinvertebrate functional feeding groups in a Chinese river system: A test for river continuum concept (RCC). Quat. Int. 2011, 244, 289-295. [CrossRef]

13. Wallace, J.B.; Webster, J.R. The role of macroinvertebrates in stream ecosystem function. Annu. Rev. Entomol. 1996, 41, 115-139. [CrossRef]

14. Covich, A.P.; Palmer, M.A.; Crowl, T.A. The role of benthic invertebrate species in freshwater ecosystems: Zoobenthic species influence energy flows and nutrient cycling. Bioscience 1999, 49, 119-127. [CrossRef]

15. Muresan, A.N.; Gaglio, M.; Aschonitis, V.; Nobili, G.; Castaldelli, G.; Fano, E.A. Structural and functional responses of macroinvertebrate communities in small wetlands of the Po delta with different and variable salinity levels. Estuar. Coast. Shelf Sci. 2020, 238, 106726. [CrossRef]

16. Rosser, Z.C.; Pearson, R.G. Hydrology, hydraulics and scale influence macroinvertebrate responses to disturbance in tropical streams. J. Freshw. Ecol. 2018, 33, 1-17. [CrossRef]

17. Permanent Secretariat of the Alpine Convention. Alpine Convention Water and Water Management Issues: Report on the State of the Alps; Permanent Secretariat of the Alpine Convention: Innsbruck, Austria, 2009; ISBN 978-8-89-043483-9.

18. Pollice, A.; Jona-Lasinio, G.; Gaglio, M.; Blanchet, F.G.; Fano, E.A. Modelling the effect of directional spatial ecological processes for a river network in Northern Italy. Ecol. Indic. 2020, 112, 106144. [CrossRef]

19. Gaglio, M.; Aschonitis, V.; Castaldelli, G.; Fano, E.A. Land use intensification rather than land cover change affects regulating services in the mountainous Adige river basin (Italy). Ecosyst. Serv. 2020, 45, 101158. [CrossRef]

20. Chiogna, G.; Majone, B.; Cano Paoli, K.; Diamantini, E.; Stella, E.; Mallucci, S.; Lencioni, V.; Zandonai, F.; Bellin, A. A review of hydrological and chemical stressors in the Adige catchment and its ecological status. Sci. Total Environ. 2016, 540, 429-443. [CrossRef] [PubMed]

21. Braioni, M.G. Faunistic research in a fluvial ecosystem study: The case of the River Adige. Bolletino di Zool. 1994, 61, 415-424. [CrossRef]

22. Pavoni, B.; Duzzin, B.; Donazzolo, R. Contamination by chlorinated hydrocarbons (DDT, PCBs) in surface sediment and macrobenthos of the river Adige (Italy). Sci. Total Environ. 1987, 65, 21-39. [CrossRef]

23. Duzzin, B.; Pavoni, B.; Donazzolo, R. Macroinvertebrate communities and sediments as pollution indicators for heavy metals in the river Adige (Italy). Water Res. 1988, 22, 1353-1363. [CrossRef]

24. Giulivo, M.; Stella, E.; Capri, E.; Esnaola, A.; López de Alda, M.; Diaz-Cruz, S.; Mandaric, L.; Muñoz, I.; Bellin, A. Assessing the effects of hydrological and chemical stressors on macroinvertebrate community in an Alpine river: The Adige River as a case study. River Res. Appl. 2019, 35, 78-87. [CrossRef]

25. De Castro-Català, N.; Dolédec, S.; Kalogianni, E.; Skoulikidis, N.T.; Paunovic, M.; Vasiljević, B.; Sabater, S.; Tornés, E.; Muñoz, I. Unravelling the effects of multiple stressors on diatom and macroinvertebrate communities in European river basins using structural and functional approaches. Sci. Total Environ. 2020, 742, 140543. [CrossRef] [PubMed] 
26. Laliberté, E.; Legendre, P. A distance-based framework for measuring functional diversity from multiple traits. Ecology 2010, 91, 299-305. [CrossRef] [PubMed]

27. MarLIN BIOTIC - Biological Traits Information Catalogue. Available online: www.marlin.ac.uk/biotic (accessed on 7 February 2021).

28. Thorp, J.H.; Covich, A.P. Ecology and Classification of North American Freshwater Invertebrates; Accademic Press: Cambridge, MA, USA, 2010; ISBN 9780123748553.

29. Krumbein, W.C.; Sloss, L.L. Stratigraphy and Sedimentation; Freeman: San Francisco, CA, USA, 1963.

30. Armstrong, F.A.J.; Stearns, C.R.; Strickland, J.D.H. The measurement of upwelling and subsequent biological process by means of the Technicon Autoanalyzerßand associated equipment. Deep. Res. Oceanogr. Abstr. 1967, 14, 381-389. [CrossRef]

31. American Public Health Association (APHA). American Public Health Association Method 3112: Standard Methods for the Examination of Water and Wastewater, 18th ed.; Greenberg, A., Clesceri, L.S., Eaton, A.D., Eds.; APHA: Washington, DC, USA, 1992.

32. Bower, C.E.; Holm-Hansen, T. A Salicylate-Hypochlorite Method for Determining Ammonia in Seawater. Can. J. Fish. Aquat. Sci. 1980, 37, 794-798. [CrossRef]

33. Henriques-Oliveira, A.L.; Nessimian, J.L. Aquatic macroinvertebrate diversity and composition in streams along an altitudinal gradient in Southeastern Brazil. Biota Neotrop. 2010, 10, 115-128. [CrossRef]

34. Wang, Y.; Liu, J.J.; Liu, W.; Feng, Q.; Li, B.L.; Lu, H.; Wang, S. Spatial variation in macrobenthic assemblages and their relationship with environmental factors in the upstream and midstream regions of the Heihe River Basin, China. Environ. Monit. Assess. 2021, 193, 1-22. [CrossRef]

35. Chiogna, G.; Skrobanek, P.; Narany, T.S.; Ludwig, R.; Stumpp, C. Effects of the 2017 drought on isotopic and geochemical gradients in the Adige catchment, Italy. Sci. Total Environ. 2018, 645, 924-936. [CrossRef]

36. Botta-Dukát, Z. Rao's quadratic entropy as a measure of functional diversity based on multiple traits. J. Veg. Sci. 2005, 16, 533-540. [CrossRef]

37. Pakeman, R.J. Functional trait metrics are sensitive to the completeness of the species' trait data? Methods Ecol. Evol. 2014, 5, 9-15. [CrossRef]

38. Rezende, R.S.; Santos, A.M.; Henke-Oliveira, C.; Gonçalves, J.F. Effects of spatial and environmental factors on benthic a macroinvertebrate community. Zoologia 2014, 31, 426-434. [CrossRef]

39. Aschonitis, V.G.; Feld, C.K.; Castaldelli, G.; Turin, P.; Visonà, E.; Fano, E.A. Environmental stressor gradients hierarchically regulate macrozoobenthic community turnover in lotic systems of Northern Italy. Hydrobiologia 2016, 765, 131-147. [CrossRef]

40. Stendera, S.; Adrian, R.; Bonada, N.; Cañedo-Argüelles, M.; Hugueny, B.; Januschke, K.; Pletterbauer, F.; Hering, D. Drivers and stressors of freshwater biodiversity patterns across different ecosystems and scales: A review. Hydrobiologia 2012, 696, 1-28. [CrossRef]

41. Calabrese, S.; Mezzanotte, V.; Marazzi, F.; Canobbio, S.; Fornaroli, R. The influence of multiple stressors on macroinvertebrate communities and ecosystem attributes in Northern Italy pre-Alpine rivers and streams. Ecol. Indic. 2020, 115, 106408. [CrossRef] 